\title{
Ekstrak Daun Avicennia alba dalam Mencegah Peningkatan Keasaman Lambung Mus musculus yang Diinduksi Aspirin
}

\author{
Nugroho Eko Wirawan Budianto ${ }^{1^{*}}$ \\ Bagian Farmakologi Universitas Wijaya Kusuma Surabaya ${ }^{1}$ \\ *e-mail: dr.nugrohoewb@yahoo.com
}

\begin{abstract}
Abstrak
Daun mangrove diekstrak dengan menggunakan etanol 96\% dan dipakai sebagai pencegahan peningkatan asam lambung dengan uji hewan coba Mus musculus. Tujuan penelitian untuk mengetahui potensi ekstrak daun Avicennia alba sebagai pencegahan peningkatan asam lambung karena induksi aspirin, dengan melihat kadar asam bebas, asam total, asam organik dan $\mathrm{pH}$ lambung Mus musculus. Metode penelitian Mus musculus dibagi dalam 5 kelompok 1). Kelompok kontrol negatif, 2). Kelompok kontrol positif, 3). 3 Kelompok perlakuan dengan dosis berbeda yaitu ekstrak daun Avicennia alba $1,3 \mathrm{mg} / 20 \mathrm{~g} \mathrm{BB}$, ekstrak daun Avicennia alba 2,6 $\mathrm{mg} / 20 \mathrm{~g} \mathrm{BB}$, ekstrak daun Avicennia alba 5,2 mg/20 g BB. Hasil menunjukan bahwa Pemberian ekstrak etanol Avicennia alba $\mathrm{P} 2$ yang diberikan secara intra oral mencegah peningkatan kadar asam bebas, asam total, asam organik dan $\mathrm{pH}$ asam lambung yang diinduksi oleh aspirin yang diberikan secara intra oral. Kesimpulan penelitian adalah ekstrak etanol Avicennia alba mencegah peningkatan kadar asam bebas, asam total, asam organik dan $\mathrm{pH}$ lambung. Ekstrak etanol Avicennia alba 2,6 mg/ $20 \mathrm{~g}$ BB merupakan dosis yang dianjurkan
\end{abstract}

Kata Kunci: Avicennia alba, aspirin, keasaman lambung

\section{Extract of Avicennia alba's Leaf Prevents the Increase of Gastric Acidity of Mus musculus induced by Aspirin}

\begin{abstract}
Mangrove leaves were extracted using ethanol $96 \%$ and were used as a prevention of increased gastric acid by testing Mus musculus. The aim of the study was to determine the potential of Avicennia alba leaf extract as a prevention of increased gastric acid due to aspirin induction, by looking at the levels of free acid, total acid, organic acid and gastric $\mathrm{pH}$ of Mus musculus. The Mus musculus research method is divided into 5 groups 1). Negative control groups, 2). Positive control group, 3). 3 Treatment groups with different doses, namely Avicennia alba leaf extract $1.3 \mathrm{mg} / 20 \mathrm{~g} \mathrm{BB}$, Avicennia alba leaf extract $2.6 \mathrm{mg} / 20 \mathrm{~g} \mathrm{BB}$, Avicennia alba leaf extract 5.2 $\mathrm{mg} / 20 \mathrm{~g} B \mathrm{~B}$. The results showed that the administration of Avicennia alba $P 2$ ethanol extract given intra-oral prevented an increase in the levels of free acid, total acid, organic acid and aspirin-induced gastric acid $\mathrm{pH}$ given intra-oral. The conclusion of the study was Avicennia alba ethanol extract prevented an increase in free acid levels, total acid, organic acids and gastric $\mathrm{pH}$. Avicennia alba ethanol extract $2.6 \mathrm{mg} / 20 \mathrm{~g} \mathrm{BB}$ is the recommended dose
\end{abstract}

Keywords: Avicennia alba, aspirin, gastric acidity 
Ekstrak Daun Avicennia alba dalam Mencegah Peningkatan Keasaman Lambung Mus muscu... Nugroho Eko Wirawan Budianto

\section{PENDAHULUAN}

Lambung sebenarnya terlindungi oleh lapisan mukus, tetapi oleh karena beberapa faktor iritan seperti makanan, minuman dan obat-obatan antiinflamasi non-steroid (NSAID), dan alkohol yang dapat menimbulkan defek lapisan mukosa sehingga timbul tukak peptik (Tarigan, 2001). Ulkus peptikum adalah keadaan rusaknya mukosa yang meluas di bawah epitel atau kerusakan pada jaringan mukosa, sub mukosa hingga lapisan otot dari suatu daerah saluran cerna yang langsung berhubungan dengan cairan lambung asam/pepsin (Sanusi, 2011)

Pada lambung normal, terdapat dua mekanisme yang bekerja dan mempengaruhi kondisi lambung, yaitu faktor pertahanan (defense) lambung dan faktor perusak (aggressive) lambung. Kedua faktor ini, pada lambung sehat, bekerja secara seimbang, sehingga lambung tidak mengalami kerusakan/luka. Apabila terjadi ketidakseimbangan antara kedua faktor diatas, baik faktor pertahanan yang melemah ataupun faktor perusak yang semakin kuat, dapat mengakibatkan kerusakan pada sel-sel lambung, yang pada akhirnya akan membentuk ulkus lambung/peptikum.

Terapi penggunaan obat ditujukan untuk meningkatkan kualitas atau mempertahankan hidup pasien. Namun ada hal-hal yang tak dapat disangkal dalam pemberian obat yaitu kemungkinan terjadinya hasil pengobatan tidak seperti yang diharapkan. Penggunaan obat yang rasional adalah sangat penting dalam terapi pengobatan pasien untuk mencegah adanya kegagalan dalam terapi pengobatan tukak peptik (Siregar dan Kumolosari, 2006). Kaitan aktivitas asam lambung yang berlebihan dengan kejadian ulkus peptikum memungkinkan penggunaan obat untuk mengurangi keasaman lambung menjadi salah satu pilihan penting dalam pengobatan ulkus peptikum.

Sekresi asam lambung basal normal rata-rata 2-4 $\mathrm{mEq} / \mathrm{jam}$ dengan dosis standar ARH-2 dapat menurunkan sekresi asam lambung hingga $60-70 \%$. Pada dosis yang sesuai semua jenis ARH-2 mempunyai efikasi yang hampir sama, tetapi secara farmakodinamik simetidin dan ranitidin memiliki sifat lebih baik dan merupakan pilihan pertama pada pengobatan ulkus peptikum pada anak (Katzung, 2007).

Risiko ulkus peptikum karena aspirin dosis rendah, LDA, (low dose aspirin, $\leq 325$ mg sehari) lebih besar pada wanita usia lanjut dibandingkan dengan pria usia lanjut. (Kazuhisa Okada, 2010. Terapi aspirin/LDA pada pasien dengan penyakit kardiovaskular dan serebrovaskular kian meningkat, juga pada pasien usia lanjut. 
Namun hal ini disertai dengan peningkatan risiko perdarahan gastroduodenal, meskipun dengan dosis kecil $(75 \mathrm{mg}$ sehari). Bila terjadi perdarahan ulkus peptikum, pemberian aspirin dihentikan hingga ulkus sembuh, walaupun penghentian terapi berarti meningkatkan risiko kejadian kardiovaskular, serebrovaskular dan kematian pada pasien. Mangrove secara biokimiawi merupakan tanaman yang unik karena kandungan metabolit sekunder yang beragam. Metabolit sekunder yang dapat terkandung pada tanaman mangrove adalah fraksi senyawa Non Saponifiable Lipid (NSL) yaitu triterpenoid, alkaloid, saponin, alkana, alkohol rantai panjang dan fitosterol (Kardaya, 2011). Mangrove terkenal kaya sebagai sumber senyawa triterpenoid dan fitosterol (isoprenoid). Salah satu kemampuan mencolok spesies mangrove adalah tumbuh dalam berbagai tingkat salinitas mulai dari air tawar sampai ketingkat di atas air laut (Rukmini, 2007)

Ekstrak daun Pohon Mangrove Avicennia alba mengandung senyawa saponin, tannin, alkaloid, triterpenoid, dan fenolik yang efektif sebagai antiinflamasi, antibakteri, dan antivirus. Daun Mangrove (Avicennia alba) mampu menghambat pertumbuhan jamur patogen danmenunjukkan aktivitas sebagai antibakteri, baik gram positif maupun gram negative dan antifungi pada konsentrasi minimal 10\% (Supriyanto, 2014). Dewasa ini belum diteliti tentang efektivitas ekstrak daun Mangrove (Avicennia alba) terhadap gasttroprotektif ulkus peptikum. Berdasarkan paparan diatas maka peneliti tertarik untuk melakukan penelitian dengan judul ekstrak daun Avicenia Alba dalam mencegah peningkatan keasaman lambung Mus musculus yang diinduksi aspirin.

\section{BAHAN DAN METODE}

Rancangan penelitian yang dilakukan menggunakan rancangan penelitian post test only control group design untuk pengamatan yang dilakukan pada 5 kelompok yang masing-masing dipilih secara random. Populasi penelitian adalah tikus (Mus musculus), usia 6-8 minggu dengan jenis kelamin jantan dan berat badan \pm 20 gram. Sampel akan dilakukan secara Simple Random Sampling. Besar sampel dapat ditentukan berdasarkan rumus Federer.

KO : Kelompok kontrol negatif $0,2 \mathrm{ml}$ $\mathrm{Na}-\mathrm{CMC} 0,5 \%$

K1 : Kelompok kontrol positif diberi $0,2 \mathrm{ml} \mathrm{Na-CMC} \mathrm{0,5 \%} \mathrm{dan} \mathrm{0,1} \mathrm{ml}$ aspirin dosis $1,7 \mathrm{mg} / 20 \mathrm{gBB}$ intraoral

P1 : Kelompok perlakuan satu diberi $0,2 \mathrm{ml}$ ekstrak daun Avicennia 
Ekstrak Daun Avicennia alba dalam Mencegah Peningkatan Keasaman Lambung Mus muscu... Nugroho Eko Wirawan Budianto

alba $1,3 \mathrm{mg} / 20 \mathrm{~g}$ BB dalam NaCMC 0,5\% peroral dan $0,1 \mathrm{ml}$ aspirin dosis $1,7 \mathrm{mg} / 20 \mathrm{~g} \mathrm{BB}$ intraoral

P2 : Kelompok perlakuan dua diberi $0,2 \mathrm{ml}$ ekstrak daun Avicennia alba $2,6 \mathrm{mg} / 20 \mathrm{~g}$ BB dalam NaCMC 0,5\% peroral dan $0,1 \mathrm{ml}$ aspirin dosis $1,7 \mathrm{mg} / 20 \mathrm{~g} \mathrm{BB}$ intraoral

P3 : Kelompok perlakuan tiga diberi 0,2 ml? ekstrak daun Avicennia alba $5,2 \mathrm{mg} / 20 \mathrm{~g}$ BB dalam NaCMC 0,5\% peroral dan 0,1 ml aspirin dosis $1,7 \mathrm{mg} / 20 \mathrm{gBB}$ intraoral

Variabel pada penelitian ini meliputi Variabel bebas: Ekstrak daun Avicennia alba, Aspirin. Variabel terikat: Asam lambung pada tikus Mus musculus. Variabel kendali: Subyek penelitian dan faktor lingkungan laboratorium.

Dosis Avicennia alba pada manusia adalah $500 \mathrm{mg} / \mathrm{kgBB}, 1000 \mathrm{mg} / \mathrm{kgBB}$, dan 2000 mg/kgBB (Kar et al., 2014). Faktor konversi manusia dengan berat badan 70 kg ke Mus musculus dengan berat badan $20 \mathrm{~g}$ adalah 0,0026 . Dosis toksik aspirin pada manusia adalah $600 \mathrm{mg} / \mathrm{kgBB}$ tikus. Dosis toksik aspirin untuk tikus berdasarkan tabel konversi manusia dengan berat badan $200 \mathrm{~g}$, dengan faktor konversi 0,14 (Rachmawati, 2010).
Dengan menyayat kurvatura mayor, lambung dibuka dan asam lambung dimasukkan kedalam tabung sentrifus dan diputar pada 2000 rpm selama 10 menit. Setiap cairan lambung dianalisa sendiri. Dicatat volume supernatant dan presipitatnya. Untuk kadar asam bebas menggunakan reagen toppfer, dan asam lambung total menggunakan indicator phenolphthalein.

\section{HASIL}

Tabel 1. Kadar asam bebas (meq/ml)

\begin{tabular}{ll}
\hline Kelompok & $(\bar{x} \pm \mathrm{SD})$ \\
\hline kontrol negatif(K0) & $0.00025 \pm 0.0000837$ \\
kontrol positif(K1) & $0.001233 \pm 0.0007202$ \\
P1 & $0.0007 \pm 0.0003899$ \\
P2 & $0.000517 \pm 0.0002994$ \\
P3 & $0.000683 \pm 0.0003710$
\end{tabular}

Tabel 2. Kadar asam total (meq/ml)

\begin{tabular}{ll}
\hline Kelompok & $(\bar{x} \pm \mathrm{SD})$ \\
\hline kontrol negatif(K0) & $0.000417 \pm 0.0001169$ \\
kontrol positif(K1) & $0.001783 \pm 0.0009131$ \\
P1 & $0.001450 \pm 0.0004324$ \\
P2 & $0.001033 \pm 0.0008454$ \\
P3 & $0.001500 \pm 0.0012198$ \\
\hline
\end{tabular}

Tabel 3. Kadar Asam Organik (meq/ml)

\begin{tabular}{ll}
\hline Kelompok & $(\bar{x} \pm$ SD $)$ \\
\hline kontrol negatif(K0) & $0.000167 \pm 0.0000516$ \\
kontrol positif(K1) & $0.00055 \pm 0.0002429$ \\
P1 & $0.00075 \pm 0.0001517$ \\
P2 & $0.000517 \pm 0.0006338$ \\
P3 & $0.000967 \pm 0.0007312$ \\
\hline
\end{tabular}

Tabel 4. $\mathrm{pH}$

\begin{tabular}{ll}
\hline Kelompok & $(\bar{x} \pm \mathrm{SD})$ \\
\hline kontrol negatif(K0) & $3.6117 \pm 0.12813$ \\
kontrol positif(K1) & $2.9633 \pm 0.24378$ \\
P1 & $3.2183 \pm 0.28799$ \\
P2 & $3.3750 \pm 0.35365$ \\
P3 & $3.2183 \pm 0.25388$ \\
\hline
\end{tabular}


ISSN 1978-2071 (Print); ISSN 2580-5967 (Online) Jurnal IImiah Kedokteran Wijaya Kusuma 8(1) : 40-53, Maret 2019

\section{UJI NORMALITAS}

\section{Tests of Normality}

\begin{tabular}{|c|c|c|c|c|c|c|c|}
\hline \multirow{2}{*}{\multicolumn{2}{|c|}{ perlakuan }} & \multicolumn{3}{|c|}{ Kolmogorov-Smirnov ${ }^{a}$} & \multicolumn{3}{|c|}{ Shapiro-Wilk } \\
\hline & & Statistic & df & Sig. & Statistic & df & Sig. \\
\hline \multirow[t]{5}{*}{ volume lambung } & kontrol negatif & 254 & 6 & $200^{n}$ & 866 & 6 & .212 \\
\hline & kontrol positif &, 219 & 6 & $200^{*}$ & 883 & 6 &, 282 \\
\hline & P1 &, 209 & 6 & $200^{*}$ &, 907 & 6 &, 415 \\
\hline & $\mathrm{P} 2$ &, 212 & 6 & $200^{*}$ & ,933 & 6 & 607 \\
\hline & P3 & 185 & 6 & $200^{*}$ & 974 & 6 & ,918 \\
\hline \multirow[t]{5}{*}{$\left(\mathrm{H}^{+}\right) \mathrm{F}$} & kontrol negatif &, 392 & 6 &, 004 &, 701 & 6 &, 006 \\
\hline & kontrol positif &, 190 & 6 & $200^{*}$ & 879 & 6 &, 263 \\
\hline & P1 & , 137 & 6 &, $200^{*}$ &, 985 & 6 &, 974 \\
\hline & $\mathrm{P} 2$ &, 230 & 6 & $200^{*}$ &, 951 & 6 &, 752 \\
\hline & P3 &, 210 & 6 & $200^{*}$ & 891 & 6 &, 326 \\
\hline \multirow[t]{5}{*}{$(\mathrm{H}+) \mathrm{T}$} & kontrol negatif & .223 & 6 & $.200^{\circ}$ & 908 & 6 & .421 \\
\hline & kontrol positif & ,202 & 6 & $200^{\circ}$ &, 905 & 6 &, 405 \\
\hline & P1 & ,218 & 6 & $200^{*}$ & ,926 & 6 &, 546 \\
\hline & $\mathrm{P} 2$ &, 396 & 6 &, 004 &, 732 & 6 &, 013 \\
\hline & P3 & 167 & 6 & $200^{*}$ & 959 & 6 & 812 \\
\hline \multirow[t]{5}{*}{$\left(\mathrm{H}^{+}\right)$organik } & kontrol negatif & .407 & 6 &, 002 & 640 & 6 & 001 \\
\hline & kontrol positif &, 232 & 6 & $200^{*}$ & ,808 & 6 &, 070 \\
\hline & P1 &, 204 & 6 & $200^{\circ}$ &, 902 & 6 &, 389 \\
\hline & $\mathrm{P} 2$ & .406 & 6 &, 002 &, 596 & 6 &, 000 \\
\hline & P3 &, 257 & 6 & $200^{\circ}$ & 877 & 6 &, 255 \\
\hline \multirow[t]{5}{*}{$\mathrm{pH}$} & kontrol negatif & 396 & 6 &, 004 &, 705 & 6 &, 007 \\
\hline & kontrol positif & , 187 & 6 & $200^{\circ}$ & ,928 & 6 &, 563 \\
\hline & P1 &, 172 & 6 & $200^{*}$ &, 959 & 6 & 810 \\
\hline & $\mathrm{P} 2$ &, 238 & 6 & $200^{\circ}$ & 881 & 6 &, 274 \\
\hline & P3 & ,273 & 6 & ,184 & 879 & 6 & 264 \\
\hline
\end{tabular}

*. This is a lower bound of the true significance.

a. Lilliefors Significance Correction

\section{UJI HOMOGENITAS DATA}

Test of Homogeneity of Variances

\begin{tabular}{|l|r|r|r|r|}
\hline & \multicolumn{1}{|c|}{$\begin{array}{l}\text { Levene } \\
\text { Statistic }\end{array}$} & \multicolumn{1}{c|}{ df1 } & \multicolumn{1}{c|}{ df2 } & \multicolumn{1}{c|}{ Sig. } \\
\hline volume lambung & 1,529 & 4 & 25 &, 224 \\
$(\mathrm{H}+)$ F & 2,818 & 4 & 25 &, 047 \\
$(\mathrm{H}+)$ T & 3,323 & 4 & 25 &, 026 \\
$(\mathrm{H}+)$ organik & 4,918 & 4 & 25 &, 005 \\
$\mathrm{pH}$ &, 956 & 4 & 25 &, 449 \\
\hline
\end{tabular}


Ekstrak Daun Avicennia alba dalam Mencegah Peningkatan Keasaman Lambung Mus muscu... Nugroho Eko Wirawan Budianto

\section{UJI ANOVA}

\begin{tabular}{|ll|r|r|r|r|r|}
\hline & \multicolumn{1}{|c|}{$\begin{array}{c}\text { Sum of } \\
\text { Squares }\end{array}$} & \multicolumn{1}{c|}{ df } & Mean Square & \multicolumn{1}{c|}{ F } & Sig. \\
\hline volume lambung & Between Groups &, 001 & 4 &, 000 &, 409 &, 800 \\
& Within Groups &, 008 & 25 &, 000 & & \\
& Total &, 009 & 29 & & & \\
\hline$(\mathrm{H}+) \mathrm{F}$ & Between Groups &, 000 & 4 &, 000 & 4,294 &, 009 \\
& Within Groups &, 000 & 25 &, 000 & & \\
& Total &, 000 & 29 & & & \\
\hline$(\mathrm{H}+) \mathrm{T}$ & Between Groups &, 000 & 4 &, 000 & 2,612 &, 060 \\
& Within Groups &, 000 & 25 &, 000 & & \\
& Total &, 000 & 29 & & & \\
\hline$(\mathrm{H}+)$ organik & Between Groups &, 000 & 4 &, 000 & 2,598 &, 061 \\
& Within Groups &, 000 & 25 &, 000 & & \\
& Total &, 000 & 29 & & & \\
\hline $\mathrm{pH}$ & Between Groups & 1,361 & 4 &, 340 & 4,885 &, 005 \\
& Within Groups & 1,742 & 25 &, 070 & & \\
& Total & 3,103 & 29 & & & \\
\hline
\end{tabular}

\section{UJI LANJUT POST HOC}

\begin{tabular}{|c|c|c|c|c|c|c|c|}
\hline \multicolumn{8}{|c|}{ Multiple Comparisons } \\
\hline \multicolumn{8}{|l|}{ LSD } \\
\hline \multirow[b]{2}{*}{ Dependent Variable } & \multirow[b]{2}{*}{ (I) perlakuan } & \multirow[b]{2}{*}{ (J) perlakuan } & \multirow{2}{*}{$\begin{array}{c}\text { Mean } \\
\text { Difference (I- } \\
\mathrm{J})\end{array}$} & \multirow[b]{2}{*}{ Std. Error } & \multirow[b]{2}{*}{ Sig. } & \multicolumn{2}{|c|}{$95 \%$ Confidence Interval } \\
\hline & & & & & & Lower Bound & Upper Bound \\
\hline \multirow[t]{20}{*}{ volume lambung } & \multirow[t]{4}{*}{ kontrol negatif } & kontrol positif &, 00833 & .01055 & .437 &,- 0134 & 0301 \\
\hline & & P1 &,- 00333 &, 01055 &, 755 &,- 0251 &, 0184 \\
\hline & & $\mathrm{P} 2$ &, 00333 & .01055 &, 755 &,- 0184 &, 0251 \\
\hline & & P3 &, 00667 &, 01055 &, 533 &,- 0151 &, 0284 \\
\hline & \multirow[t]{4}{*}{ kontrol positif } & kontrol negatif &,- 00833 & .01055 &, 437 &,- 0301 &, 0134 \\
\hline & & P1 &,- 01167 & .01055 & .279 &,- 0334 &, 0101 \\
\hline & & P2 &,- 00500 &, 01055 & .640 &,- 0267 &, 0167 \\
\hline & & P3 &,- 00167 & .01055 & 876 &,- 0234 &, 0201 \\
\hline & \multirow[t]{4}{*}{ P1 } & kontrol negatif & 00333 & .01055 &, 755 &,- 0184 & 0251 \\
\hline & & kontrol positif &, 01167 & .01055 &, 279 &,- 0101 &, 0334 \\
\hline & & $\mathrm{P} 2$ &, 00667 &, 01055 & .533 &,- 0151 &, 0284 \\
\hline & & P3 & .01000 & .01055 &, 352 &,- 0117 &, 0317 \\
\hline & \multirow[t]{4}{*}{$\mathrm{P} 2$} & kontrol negatif &,- 00333 & .01055 &, 755 &,- 0251 & .0184 \\
\hline & & kontrol positif &, 00500 & .01055 & .640 &,- 0167 &, 0267 \\
\hline & & P1 &,- 00667 &, 01055 & .533 &,- 0284 &, 0151 \\
\hline & & P3 &, 00333 & .01055 &, 755 & -.0184 &, 0251 \\
\hline & \multirow[t]{4}{*}{ P3 } & kontrol negatif &,- 00667 & .01055 & .533 &,- 0284 & 0151 \\
\hline & & kontrol positif &, 00167 &, 01055 &, 876 &,- 0201 &, 0234 \\
\hline & & P1 &,- 01000 &, 01055 &, 352 &,- 0317 &, 0117 \\
\hline & & P2 &,- 00333 &, 01055 &, 755 &,- 0251 &, 0184 \\
\hline \multirow[t]{20}{*}{$\mathrm{pH}$} & \multirow[t]{4}{*}{ kontrol negatif } & kontrol positif & $.64833^{x}$ & , 15238 & .000 & .3345 &, 9622 \\
\hline & & $\mathrm{P} 1$ &, $39333^{x}$ & , 15238 &, 016 &, 0795 &, 7072 \\
\hline & & P2 &, 23667 & , 15238 &, 133 &,- 0772 &, 5505 \\
\hline & & P3 &, $39333^{\star}$ &, 15238 & .016 &, 0795 &, 7072 \\
\hline & \multirow[t]{4}{*}{ kontrol positif } & kontrol negatif &,$- 64833^{x}$ & , 15238 & .000 &,- 9622 &,- 3345 \\
\hline & & P1 &,- 25500 & 15238 & .107 &,- 5688 &, 0588 \\
\hline & & P2 &,$- 41167^{*}$ &, 15238 & .012 &,- 7255 &,- 0978 \\
\hline & & P3 &,- 25500 & .15238 & .107 &,- 5688 &, 0588 \\
\hline & \multirow[t]{4}{*}{$\mathrm{P} 1$} & kontrol negatif &,$- 39333^{x}$ & , 15238 & .016 &,- 7072 &,- 0795 \\
\hline & & kontrol positif &, 25500 & .15238 &, 107 &,- 0588 &, 5688 \\
\hline & & $\mathrm{P} 2$ &,- 15667 & , 15238 &, 314 &,- 4705 & ,1572 \\
\hline & & P3 &, 00000 & , 15238 & 1,000 &,- 3138 &, 3138 \\
\hline & \multirow[t]{4}{*}{$\mathrm{P} 2$} & kontrol negatif &,- 23667 & , 15238 & .133 &,- 5505 & .0772 \\
\hline & & kontrol positif & $41167^{*}$ & 15238 &, 012 &, 0978 &, 7255 \\
\hline & & P1 &, 15667 & , 15238 &, 314 &,- 1572 &, 4705 \\
\hline & & P3 &, 15667 & .15238 & .314 &,- 1572 &, 4705 \\
\hline & \multirow[t]{4}{*}{ P3 } & kontrol negatif &,$- 39333^{x}$ & , 15238 & 016 &,- 7072 &,- 0795 \\
\hline & & kontrol positif &, 25500 &, 15238 & 107 &,- 0588 & 5688 \\
\hline & & P1 &, 00000 & , 15238 & 1,000 &,- 3138 &, 3138 \\
\hline & & $\mathrm{P} 2$ &,- 15667 &, 15238 &, 314 &,- 4705 &, 1572 \\
\hline
\end{tabular}

*. The mean difference is significant at the 0.05 level. 
ISSN 1978-2071 (Print); ISSN 2580-5967 (Online)

Jurnal IImiah Kedokteran Wijaya Kusuma 8(1) : 40-53, Maret 2019

Multiple Comparisons

LSD

\begin{tabular}{|c|c|c|c|c|c|c|c|}
\hline \multirow[b]{2}{*}{ Dependent Variable } & \multirow[b]{2}{*}{ (1) perlakuan } & \multirow[b]{2}{*}{ (J) perlakuan } & \multirow{2}{*}{$\begin{array}{c}\text { Mean } \\
\text { Difference (I- } \\
\mathrm{J})\end{array}$} & \multirow[b]{2}{*}{ Std. Error } & \multirow[b]{2}{*}{ Sig. } & \multicolumn{2}{|c|}{$95 \%$ Confidence Interval } \\
\hline & & & & & & Lower Bound & Upper Bound \\
\hline \multirow[t]{20}{*}{$(\mathrm{H}+) \mathrm{F}$} & \multirow[t]{4}{*}{ kontrol negatif } & kontrol positif &,$- 0009833^{x}$ &, 0002456 &, 000 &,- 001489 &,- 000477 \\
\hline & & P1 &,- 0004500 &, 0002456 &, 079 &,- 000956 &, 000056 \\
\hline & & $\mathrm{P} 2$ &,- 0002667 &, 0002456 & ,288 &,- 000773 &, 000239 \\
\hline & & P3 &,- 0004333 &, 0002456 &, 090 &,- 000939 &, 000073 \\
\hline & \multirow[t]{4}{*}{ kontrol positif } & kontrol negatif &, $0009833^{x}$ &, 0002456 &, 000 &, 000477 &, 001489 \\
\hline & & P1 &, $0005333^{\star}$ &, 0002456 &, 040 &, 000027 &, 001039 \\
\hline & & $\mathrm{P} 2$ &, $0007167^{n}$ &, 0002456 &, 007 &, 000211 &, 001223 \\
\hline & & $\mathrm{P} 3$ &, $0005500^{*}$ &, 0002456 &, 034 &, 000044 &, 001056 \\
\hline & \multirow[t]{4}{*}{ P1 } & kontrol negatif &, 0004500 &, 0002456 & 079 &,- 000056 &, 000956 \\
\hline & & kontrol positif &,$- 0005333^{*}$ &, 0002456 &, 040 &,- 001039 &,- 000027 \\
\hline & & $\mathrm{P} 2$ &, 0001833 &, 0002456 & 462 &,- 000323 &, 000689 \\
\hline & & $\mathrm{P} 3$ &, 0000167 &, 0002456 &, 946 &,- 000489 &, 000523 \\
\hline & \multirow[t]{4}{*}{$\mathrm{P} 2$} & kontrol negatif &, 0002667 &, 0002456 & ,288 &,- 000239 &, 000773 \\
\hline & & kontrol positif &,$- 0007167^{\star}$ &, 0002456 &, 007 &,- 001223 &,- 000211 \\
\hline & & P1 &,- 0001833 &, 0002456 &, 462 &,- 000689 &, 000323 \\
\hline & & $\mathrm{P} 3$ &,- 0001667 &, 0002456 &, 504 &,- 000673 &, 000339 \\
\hline & \multirow[t]{4}{*}{$\mathrm{P} 3$} & kontrol negatif &, 0004333 &, 0002456 &, 090 &,- 000073 &, 000939 \\
\hline & & kontrol positif &,$- 0005500^{x}$ &, 0002456 &, 034 &,- 001056 &,- 000044 \\
\hline & & P1 &,- 0000167 &, 0002456 &, 946 &,- 000523 &, 000489 \\
\hline & & $\mathrm{P} 2$ &, 0001667 &, 0002456 &, 504 &,- 000339 &, 000673 \\
\hline \multirow[t]{20}{*}{$(\mathrm{H}+) \mathrm{T}$} & \multirow[t]{4}{*}{ kontrol negatif } & kontrol positif &,$- 0013667^{x}$ &, 0004645 &, 007 &,- 002323 &,- 000410 \\
\hline & & P1 &,$- 0010333^{x}$ &, 0004645 &, 035 &,- 001990 &,- 000077 \\
\hline & & $\mathrm{P} 2$ &,- 0006167 &, 0004645 & , 196 &,- 001573 &, 000340 \\
\hline & & P3 &,$- 0010833^{x}$ &, 0004645 &, 028 &,- 002040 &,- 000127 \\
\hline & \multirow[t]{4}{*}{ kontrol positif } & kontrol negatif & $0013667^{*}$ &, 0004645 &, 007 &, 000410 &, 002323 \\
\hline & & P1 &, 0003333 &, 0004645 &, 480 &,- 000623 &, 001290 \\
\hline & & $\mathrm{P} 2$ &, 0007500 &, 0004645 & .119 &,- 000207 &, 001707 \\
\hline & & P3 &, 0002833 &, 0004645 &, 547 &,- 000673 &, 001240 \\
\hline & \multirow[t]{4}{*}{ P1 } & kontrol negatif &, $0010333^{x}$ &, 0004645 &, 035 &, 000077 &, 001990 \\
\hline & & kontrol positif &,- 0003333 &, 0004645 &, 480 &,- 001290 &, 000623 \\
\hline & & $\mathrm{P} 2$ &, 0004167 &, 0004645 &, 378 &,- 000540 &, 001373 \\
\hline & & $\mathrm{P} 3$ &,- 0000500 &, 0004645 &, 915 &,- 001007 &, 000907 \\
\hline & \multirow[t]{4}{*}{$\mathrm{P} 2$} & kontrol negatif &, 0006167 &, 0004645 &, 196 &,- 000340 &, 001573 \\
\hline & & kontrol positif &,- 0007500 &, 0004645 &, 119 &,- 001707 &, 000207 \\
\hline & & P1 &,- 0004167 &, 0004645 &, 378 &,- 001373 &, 000540 \\
\hline & & $\mathrm{P} 3$ &,- 0004667 &, 0004645 &, 325 &,- 001423 &, 000490 \\
\hline & \multirow[t]{4}{*}{ P3 } & kontrol negatif &, $0010833^{x}$ &, 0004645 &, 028 &, 000127 &, 002040 \\
\hline & & kontrol positif &,- 0002833 &, 0004645 &, 547 &,- 001240 &, 000673 \\
\hline & & P1 &, 0000500 &, 0004645 & ,915 &,- 000907 &, 001007 \\
\hline & & $\mathrm{P} 2$ & 0004667 & .0004645 & 325 & -.000490 & .001423 \\
\hline
\end{tabular}

*. The mean difference is significant at the 0.05 level. 
Ekstrak Daun Avicennia alba dalam Mencegah Peningkatan Keasaman Lambung Mus muscu... Nugroho Eko Wirawan Budianto

Multiple Comparisons

Dependent Variable: $\left(\mathrm{H}^{+}\right)$organik

LSD

\begin{tabular}{|c|c|c|c|c|c|c|}
\hline \multirow[b]{2}{*}{ (1) perlakuan } & \multirow[b]{2}{*}{ (J) perlakuan } & \multirow{2}{*}{$\begin{array}{c}\text { Mean } \\
\text { Difference (I- } \\
\mathrm{J})\end{array}$} & \multirow[b]{2}{*}{ Std. Error } & \multirow[b]{2}{*}{ Sig. } & \multicolumn{2}{|c|}{$95 \%$ Confidence Interval } \\
\hline & & & & & Lower Bound & Upper Bound \\
\hline \multirow[t]{4}{*}{ kontrol negatif } & kontrol positif &,- 0003833 &, 0002609 & 154 &,- 000921 &, 000154 \\
\hline & P1 &,$- 0005833^{x}$ & .0002609 &, 035 &,- 001121 &,- 000046 \\
\hline & $\mathrm{P} 2$ &,- 0003500 &, 0002609 &, 192 &,- 000887 &, 000187 \\
\hline & P3 &,$- 0008000^{x}$ & .0002609 &, 005 &,- 001337 &,- 000263 \\
\hline \multirow[t]{4}{*}{ kontrol positif } & kontrol negatif &, 0003833 &, 0002609 & 154 &,- 000154 &, 000921 \\
\hline & P1 &,- 0002000 &, 0002609 & ,451 &,- 000737 &, 000337 \\
\hline & $\mathrm{P} 2$ &, 0000333 &, 0002609 & ,899 &,- 000504 &, 000571 \\
\hline & P3 &,- 0004167 &, 0002609 & 123 &,- 000954 &, 000121 \\
\hline \multirow[t]{4}{*}{$\mathrm{P} 1$} & kontrol negatif &, $0005833^{x}$ &, 0002609 &, 035 &, 000046 &, 001121 \\
\hline & kontrol positif &, 0002000 &, 0002609 & 451 &,- 000337 &, 000737 \\
\hline & P2 &, 0002333 &, 0002609 &, 380 &,- 000304 &, 000771 \\
\hline & P3 &,- 0002167 &, 0002609 &, 414 &,- 000754 &, 000321 \\
\hline \multirow[t]{4}{*}{$\mathrm{P} 2$} & kontrol negatif &, 0003500 & .0002609 & .192 &,- 000187 &, 000887 \\
\hline & kontrol positif &,- 0000333 &, 0002609 &, 899 &,- 000571 &, 000504 \\
\hline & P1 &,- 0002333 &, 0002609 &, 380 &,- 000771 &, 000304 \\
\hline & P3 &,- 0004500 &, 0002609 &, 097 &,- 000987 &, 000087 \\
\hline \multirow[t]{4}{*}{ P3 } & kontrol negatif &, $0008000^{*}$ &, 0002609 &, 005 &, 000263 &, 001337 \\
\hline & kontrol positif &, 0004167 &, 0002609 & , 123 &,- 000121 &, 000954 \\
\hline & P1 &, 0002167 &, 0002609 & 414 &,- 000321 &, 000754 \\
\hline & $\mathrm{P} 2$ &, 0004500 &, 0002609 &, 097 &,- 000087 &, 000987 \\
\hline
\end{tabular}

*. The mean difference is significant at the 0.05 level.

\section{PEMBAHASAN}

Ulkus peptikum adalah kondisi dimana terjadi kerusakan pada mukosa lambung disertai dengan adanya inflamasi yang disebabkan oleh aktivitas pepsin dan asam lambung (Indraswari, 2004). Penelitian ini bertujuan untuk mengetahui pengaruh pemberian ekstrak daun mangrove (Avicennia alba) terhadap pencegahan terjadinya ulkus peptikum mencit (Mus musculus) yang diinduksi aspirin. Penggunaan sampel hewan coba berupa mencit (Mus musculus) jantan dengan dasar pertimbangan sifat jenis kelamin jantan yang lebih mudah dikontrol dalam penelitian sehingga diharapkan tidak ada pengaruh hormonal dalam proses penyembuhan, selain itu mencit (Mus musculus) merupakan mamalia yang mempunyai metabolisme sama dengan manusia (Guyton, 2007). Mus musculus betina lebih rentan terhadap stress perlakuan fisik seperti penimbangan dan penggantian sekam (Sagala, 2010).

Kadar asam bebas tertinggi adalah pada kelompok P1. Kadar asam bebas terendah adalah pada kelompok K1. Kadar 
asam bebas pada kelompok KO adalah $0,00025 \mathrm{mmol} / \mathrm{ml}$ sedangkan kadar asam bebas pada kelompok K1 adalah 0,001233 $\mathrm{mmol} / \mathrm{ml}$ berbeda bermakna secara statistik. Hal ini menunjukkan bahwa dengan pemberian aspirin menyebabkan meningkatnya kadar asam bebas secara bermakna. Kadar asam bebas pada kelompok K1 adalah 0,001233 $\mathrm{mmol} / \mathrm{ml}$ sedangkan kadar asam bebas pada kelompok P1 adalah $0,0007 \mathrm{mmol} / \mathrm{ml}$ berbeda bermakna secara statistik, hal ini menunjukkan pemberian ekstrak Avicennia alba P1 berhasil. Kadar asam bebas pada kelompok K1 adalah 0,001233 $\mathrm{mmol} / \mathrm{ml}$ sedangkan kadar asam bebas pada kelompok P2 adalah 0,000517 $\mathrm{mmol} / \mathrm{ml}$ berbeda bermakna secara statistik, hal ini menunjukkan pemberian ekstrak Avicinea alba P2 berhasil. Kadar asam bebas pada kelompok $\mathrm{K} 1$ adalah $0,001233 \mathrm{mmol} / \mathrm{ml}$ sedangkan kadar asam bebas pada kelompok P3 adalah 0,000683 $\mathrm{mmol} / \mathrm{ml}$ berbeda bermakna secara statistik, hal ini menunjukkan pemberian ekstrak Avicinea alba P3 berhasil. Kelompok P1, P2 dan P3 dapat menurunkan kadar asam bebas.

Kadar asam total tertinggi adalah pada kelompok K1. Kadar asam total terendah adalah pada kelompok P2. Kadar asam total pada kelompok KO adalah $0,000417 \mathrm{mmol} / \mathrm{ml}$ sedangkan kadar asam total pada kelompok K1 adalah 0,001783 $\mathrm{mmol} / \mathrm{ml}$, hal ini menunjukkan bahwa dengan pemberian aspirin menyebabkan meningkatnya kadar asam total bermakna. Kadar asam total pada kelompok K1 adalah 0,001783 $\mathrm{mmol} / \mathrm{ml}$ sedangkan kadar asam total P1 adalah $0,001450 \mathrm{mmol} / \mathrm{ml}$ tidak bermakna secara statistik, hal ini menunjukkan pemberian ekstrak Avicennia alba P1 tidak menurunkan kadar asam total. Kadar asam total pada kelompok K1 adalah 0,001783 $\mathrm{mmol} / \mathrm{ml}$ sedangkan kadar asam total P2 adalah 0,001033 $\mathrm{mmol} / \mathrm{ml}$ tidak bermakna secara statistik, hal ini menunjukkan pemberian ekstrak Avicinea alba P2 tidak menurunkan kadar asam total. Kadar asam total pada kelompok K1 adalah 0,001783 $\mathrm{mmol} / \mathrm{ml}$ sedangkan kadar asam total P3 adalah $0,001500 \mathrm{mmol} / \mathrm{ml}$ tidak bermakna secara statistik, hal ini menunjukkan pemberian ekstrak Avicinea alba P3 tidak menurunkan kadar asam total. Kadar asam total pada kelompok KO adalah 0,000417 $\mathrm{mmol} / \mathrm{ml}$ sedangkan kadar asam total P2 adalah $0,001033 \mathrm{mmol} / \mathrm{ml}$ tidak bermakna secara statistik hal ini menunjukkan P2 lebih efektif menurunkan kadar asam total dibanding P1 dan P2

Kadar asam organik tertinggi adalah pada kelompok P3. Kadar asam organik terendah adalah pada kelompok KO. Kadar asam organik pada kelompok KO adalah 0,000167 $\mathrm{mmol} / \mathrm{ml}$ sedangkan kadar asam 
Ekstrak Daun Avicennia alba dalam Mencegah Peningkatan Keasaman Lambung Mus muscu... Nugroho Eko Wirawan Budianto

organik pada kelompok K1 adalah 0,00055 $\mathrm{mmol} / \mathrm{ml}$ tidak berbeda bermakna secara statistik, hal ini menunjukkan bahwa dengan pemberian aspirin tidak menyebabkan meningkatnya kadar asam organik. Kadar asam organik pada kelompok $\mathrm{K} 1$ adalah $0,00055 \mathrm{mmol} / \mathrm{ml}$ sedangkan kadar asam organik P1 adalah 0,00075 $\mathrm{mmol} / \mathrm{mltidak}$ bermakna secara statistik, hal ini menunjukkan pemberian ekstrak Avicinea alba P1 tidak menurunkan kadar asam organic. Kadar asam organik pada kelompok K1 adalah 0,00055 $\mathrm{mmol} / \mathrm{ml}$ sedangkan kadar asam organik P2 adalah 0,000517 $\mathrm{mmol} / \mathrm{mltidak}$ bermakna secara statistik, hal ini menunjukkan pemberian ekstrak Avicennia alba P2 tidak menurunkan kadar asam organic. Kadar asam organik pada kelompok K1 adalah 0,00055 $\mathrm{mmol} / \mathrm{ml}$ sedangkan kadar asam organik P3 adalah 0,000967 $\mathrm{mmol} / \mathrm{mltidak}$ bermakna secara statistik, hal ini menunjukkan pemberian ekstrak Avicennia alba P3 tidak menurunkan kadar asam organic. Kadar asam organik pada kelompok KO adalah 0,000167 $\mathrm{mmol} / \mathrm{ml}$ sedangkan kadar asam organik P2 adalah $0,000517 \mathrm{mmol} / \mathrm{ml}$ tidak bermakna secara statistik, hal ini menunjukkan P2 lebih efektif menurunkan kadar asam organic dibandingkan P1 dan P3.
pH pada kelompok $\mathrm{KO}$ adalah 3,6117 sedangkan pH pada kelompok K1 adalah 2,9633 berbeda bermakna secara statistik, hal ini menunjukkan bahwa dengan pemberian aspirin menyebabkan penurunan $\mathrm{pH}$ (semakin asam). $\mathrm{pH}$ pada kelompok K1 adalah 2,9633 sedangkan pH pada kelompok P1 adalah 3,2183 tidak berbeda bermakna secara statistik, berarti ekstrak Avicinea alba P1 tidak dapat mencegah penurunan $\mathrm{pH} . \mathrm{pH}$ pada kelompok K1 adalah 2,9633 sedangkan pH pada kelompok P2 adalah 3,375 berbeda bermakna secara statistik, berarti ekstrak Avicinea alba P2 dapat mencegah penurunan $\mathrm{pH}$. $\mathrm{pH}$ pada kelompok K1 adalah 2,9633 sedangkan $\mathrm{pH}$ pada kelompok P3 adalah 3,2183 tidak berbeda bermakna secara statistik. berarti ekstrak Avicinea alba P3 tidak dapat mencegah penurunan $\mathrm{pH}$. Jadi ekstrak Avicinea alba P2 efektif menurunkan kadar $\mathrm{pH}$.

Dosis terapeutik antasid yang dibutuhkan pada ulkus peptikum relatif besar dan harus diberikan 1 sampai 3 jam setelah makan dan saat tidur, sehingga menimbulkan ketidaknyamanan bagi pasien. Dasar pengobatan ulkus peptikum berkembang dengan ditemukannya penghambat sekresi asam lambung, seperti antagonis muskarinik (antikolinergik), ARH2, dan penghambat pompa proton. Reseptor H-2, sebuah subtipe reseptor 
histamin, ditemukan oleh Sir James Black pada tahun 1971, sebagai mediator penting dalam asam lambung. Reseptor histamin berada pada lapisan basolateral dan sel parietal. Adanya histamin pada reseptor $\mathrm{H}-2$ akan mengaktifasi adenilsiklase dan terjadi peningkatan konsentrasi cyclic-adenosin monophosphate (c-AMP) intraselular. Peningkatan konsentrasi c-AMP mengaktifasi pompa proton (hidroksida kalium ATP-ase) pada sel parietal untuk mensekresi ion hidrogen $(\mathrm{H}+)$ menggantikan posisi ion kalium $\left(\mathrm{K}^{+}\right)$. ARH-2 secara selektif dan kompetitif menghambat pengikatan histamin pada reseptor $\mathrm{H}-2$, selanjutnya menurunkan konsentrasi cAMP dan menurunkan sekresi ion hidrogen pada sel parietal. Secara struktural ARH-2 tidak menyerupai antagonis reseptor $\mathrm{H}-1$, sehingga relatif tidak mempengaruhi efek penghambatan pada reseptor $\mathrm{H}-1$ ataupun reseptor autonomik (Katzung, 2007)

Penelitian ini bertujuan untuk mengetahui pengaruh pemberian ekstrak daun mangrove (Avicennia alba) terhadap pencegahan peningkatan keasaman lambung pada (Mus musculus) yang diinduksi aspirin. Penggunaan sampel hewan coba berupa mencit (Mus musculus) jantan dengan dasar pertimbangan sifat jenis kelamin jantan yang lebih mudah dikontrol dalam penelitian sehingga diharapkan tidak ada pengaruh hormonal dalam proses penyembuhan, selain itu mencit (Mus musculus) merupakan mamalia yang mempunyai metabolisme sama dengan manusia (Guyton, 2007).

Penyebab umum dari ulkus peptikum adalah ketidakseimbangan antara kecepatan sekresi cairan lambung dan derajat perlindungan yang diberikan oleh sawar mukosa gastroduodenal dan netralisasi asam lambung oleh sawar mukosa gastroduodenal dan netralisasi asam lambung oleh getah duodenum (Putri, 2013). Salah satu penyebab ulkus peptikum yaitu penggunaan aspirin. Dimana aspirin dapat menghambat COX-1. Dimukosa lambung COX-1 menghasilkan prostaglandin yang bersifat sitoprotektif. Penghambatan ini mengakibatkan konsersi asam arachidonat menjadi prostaglandin terganggu (Agoramorthy, 2008).

Hambatan pada COX-1 dapat menyebabkan turunnya sintesa prostaglandin. Penurunan sintesa prostaglandin menyebabkan penurunan sekresi mukus dan bikarbonat epitel, aliran darah mukosa, dan proliferasi epitel. Peningkatan permeabilitas akibat aspirin dapat menyebabkan difusi balik $\mathrm{H}^{+}$ke dalam mukosa lambung. Hal ini merangsang pengeluaran histamin lokal yang kemudian histamin akan berikatan dengan reseptornya pada sel parietal 
Ekstrak Daun Avicennia alba dalam Mencegah Peningkatan Keasaman Lambung Mus muscu... Nugroho Eko Wirawan Budianto

lambung yang akhirnya dapat meningkatkan sekresi asam lambung oleh sel parietal. Pembentukan radikal bebas meningkat pada OAINS yang dapat memperberat kerusakan mukosa gastrointestinal melalui kerusakan membrane sel, perubahan kode genetic, dan kerusakan DNA. Radikal bebas yang paling reaktif yaitu hydroxyl, apabila terbentuk didekat membrane sel akan menyebabkan terjadinya peroksidasi lipid pada membrane sel. Kandungan ekstrak daun mangrove mampu meredam radikal bebas yang terbentuk akibat induksi aspirin sehingga menurunkan semua parameter penelitian ini. (Diamita, 2009; Rachmawati,2010).

\section{KESIMPULAN}

Terdapat hubungan antara peningkatan dosis ekstrak daun mangrove Avicennia alba dengan kadar asam lambung Mus musculus yang diinduksi histamine sehingga Pada penelitian ini pemberian ekstrak daun Avicennia alba secara intra oral sebelum induksi aspirin dapat mencegah peningkatan kadar asam lambung Mus musculus.

\section{SARAN}

1. Hasil penelitian ini diharapkan dapat mendorong peneliti lain melakukan penelitian lebih lanjut mengenai manfaat daun mangrove (Avicennia $a / b a)$ secara ilmiah.

2. Ekstraksi etanol Daun mangrove dapat dipakai terapi alternative untuk pencegahan pada kasus ulkus peptikum

\section{DAFTAR PUSTAKA}

Agoramoorthy GF, Chen V, Venkatesalu DH, Kuo and Shea, 2008. Evaluation of Antioxidant Polyphenols from Selected Mangrove Plants of India. Asian J. of Chem., 20 (2), 1311-1322.

Clough B, Tan DT, Phuong DX, and Buu DC, 2000. Canopy Leaf Area Index and Litter Fall in Stands of the Mangrove Rhizophora apiculata of Different Age in the Mekong Delta, Vietnam. Aquat. Bot. 66: 311-320.

Diamita AA, 2009. Pengaruh Pemberian Minyak Wijen (Sesamum indicum Linn.) Dengan Cold Press Bertingkat Terhadap Kerusakan Histologis Lambung Mencit (Mus musculus) yang Diinduksi Aspirin. Skripsi. Universitas Sebelas Maret, Fakultas Kedokteran, Surakarta.

Donato DC, Kauffman JB, Murdiyarso D, Kurnianto S, Stidham $M$ dan Kanninen M, 2012. Mangrove 
Salah Satu Hutan Terkaya Karbon

di Daerah Tropis. Brief CIFOR, 12:1- 12

Guyton AC and Hall, J.E, 2007. Buku Ajar Fisiologi Kedokteran. Edisi 9. Jakarta: EGC.

Indraswari Cl, Kalsum U, Sudjari, 2004. Pengaruh Pemberian Temulawak Pada Lambung Tikus yang Mengalami Ulkus Peptikum Akibat Induksi Indometasin. Jurnal Kedokteran Brawijaya. 20(2):96-99.

Katzung BG, 2007. Basic and clinical pharmacology. Edisi ke-5. Norwalk: Appleton \& Lange. h. 238-9.

Kardaya D, Ralahalu TN, Zubir, 2011. Jurnal Ilmu dan Teknologi Peternakan 1(2). Publisher: Fakultas Peternakan Universitas Hasanuddin

Putri DTW, 2013. Pengaruh pemberian Ekstrak Etanol Daun mangrove Api-Api Putih terhadap Kesembuhan Ulkus Traumatikus.

FKG UHT. Surabaya

Rachmawati, P. 2010. Efek Perlindungan

Ekstrak Meniran (Phyllanthus

Niruri Linn.) Terhadap Kerusakan

Histologis Lambung Mencit (Mus

Musculus) Yang Diinduksi Aspirin.

Skripsi. Universitas Sebelas
Maret, Fakultas Kedokteran, Surakarta.

Rukmini A, 2007. Regenerasi Minyak Goreng Bekas Dengan Arang Sekam Menekan Kerusakan Organ Tubuh. Seminar Nasional Teknologi.

Sagala, 2010. Efek Proteksi Jus Alpukat (Persea americana mill Mencit yang diinduksi Aspirin. FK Universitas Sebelas Maret Surakarta.

Sanusi IA, 2011. Tukak Lambung. In A. A. Rani, M. S. K., \& A. F. Syam (Eds.), Buku Ajar Gastroenterologi (328345). Jakarta: Interna Publishing.

Siregar CA, dan Dharmawan IWS, 2011. Stok Karbon Tegakan Hutan Alam Dipterokarpa di PT Sarpatim, Kalimantan Tengah. Jurnal Penelitian Hutan dan Konservasi Alam. 8(4):337-348.

Supriharyono, 2009. Konservasi Ekosistem Sumberdaya Hayati di Wilayah Pesisir dan Laut Tropis. Pustaka Pelajar. Yogyakarta.

Supriyanto, Indriyanto, dan Bintoro A, 2014. Inventarisasi Jenis Tumbuhan Obat di Hutan Mangrove Desa Margasari Kecamatan Labuhan Maringgai Lampung Timur. Jurnal Sylva Lestari, 2(1): 67-75. 
Ekstrak Daun Avicennia alba dalam Mencegah Peningkatan Keasaman Lambung Mus muscu... Nugroho Eko Wirawan Budianto

Tarigan P, 2001. Sirosis Hati. Buku Ajar

Jakarta: Balai Penerbit FKUI

Penyakit Dalam jilid 1 Ed. 3 